\title{
Source terms for benchmarking models of SARS-CoV-2 transmission via aerosols and droplets
}

Marc E.J. Stettler*1, Robert T. Nishida ${ }^{2}$, Pedro M. de Oliveira ${ }^{3}$, Léo C.C. Mesquita ${ }^{3}$, Tyler J. Johnson ${ }^{3}$, Edwin R. Galea ${ }^{4}$, Angus Grandison ${ }^{4}$, John Ewer ${ }^{4}$, David Carruthers ${ }^{5}$, David Sykes $^{6}$, Prashant Kumar ${ }^{7}$, Eldad Avital ${ }^{8}$, Asiri I.B. Obeysekara ${ }^{9}$, Denis Doorly ${ }^{10}$, Yannis Hardalupas $^{11}$, David C. Green ${ }^{12}$, Simon Coldrick ${ }^{13}$, Simon Parker ${ }^{14}$, and Adam M. Boies ${ }^{3}$

${ }^{1}$ Department of Civil and Environmental Engineering, Imperial College London, London, SW7 2AZ, UK

${ }^{2}$ Department of Mechanical Engineering, University of Alberta, Edmonton, Alberta, T6G 2G8, Canada

${ }^{3}$ Department of Engineering, University of Cambridge, Cambridge, CB2 1PZ, UK

${ }^{4}$ Fire Safety Engineering Group, University of Greenwich, London, SE10 9LS, UK

${ }^{5}$ Cambridge Environmental Research Consultants Ltd, 3 Kings Parade, Cambridge, CB2 1SJ, UK

${ }^{6}$ AEROS Consultancy, Glasgow, G3 8SE, UK

${ }^{7}$ Global Centre for Clean Air Research (GCARE), Department of Civil and Environmental Engineering, Faculty of Engineering and Physical Sciences, University of Surrey, Guildford GU2 7XH, UK

${ }^{8}$ School of Engineering and Materials Science, Queen Mary University of London, London, E1 4NS, UK

${ }^{9}$ Applied Modelling and Computation Group, Department of Earth Science and Engineering, Imperial College London, London, SW7 2AZ, UK

${ }^{10}$ Department of Aeronautics, Imperial College London, London, SW7 2AZ, UK

${ }^{11}$ Department of Mechanical Engineering, Imperial College London, London, SW7 2AZ, UK

${ }^{12}$ Environmental Research Group, School of Public Health, Imperial College London, London, W12 0BZ, UK

${ }^{13}$ Health and Safety Executive, Harpur Hill, Buxton, Derbyshire, SK17 9JN

${ }^{14}$ Defence Science and Technology Laboratory, Porton Down, Salisbury, SP4 0JQ, UK

\begin{abstract}
There is ongoing and rapid advancement in approaches to modelling the fate of exhaled particles in different environments relevant to disease transmission. It is important that models are verified by comparison with each other using a common set of input parameters to ensure that model differences can be interpreted in terms of model physics rather than unspecified differences in model input parameters. In this paper, we define parameters necessary for such benchmarking
\end{abstract}

*m.stettler@imperial.ac.uk 
of models of airborne particles exhaled by humans and transported in the environment during breathing and speaking.

\section{Introduction}

Humans exhale particles made up primarily of respiratory fluid when breathing out, speaking, coughing, sneezing, singing and laughing and these particles may contain infectious pathogens (Stelzer-Braid et al., 2009; Yan et al., 2018). The size of exhaled particles spans several orders of magnitude and particle diameters range between $0.01-1000 \mu \mathrm{m}$ (Bake, Larsson, Ljungkvist, Ljungström, \& Olin, 2019). Historically, these particles have been classified in two categories by the infectious disease community: particles smaller than $5 \mu \mathrm{m}$ in diameter are referred to as droplet nuclei or aerosols, whereas particles larger than $5 \mu \mathrm{m}$ in diameter are classified as respiratory droplets (Milton, 2020; WHO, 2014). This somewhat arbitrary size classification implicitly refers to the transmission modes/mechanisms, namely airborne or droplet transmission, respectively. However, the connection between particle diameter (droplets vs aerosols) and the description of transmission mode/mechanisms (droplet vs airborne transmission) can lead to misunderstanding. For example, it is untrue in general that particles with diameter $>5 \mu \mathrm{m}$ fall quickly onto a surface close to their source since these particles, particularly those $\sim 5-10 \mu \mathrm{m}$ in diameter, can be advected with ventilation flows over longer distances and remain airborne for longer periods. Consequently, Prather et al. (2020) recommend that aerosols and droplets are distinguished by a threshold of particle diameter of $100 \mu \mathrm{m}$, which more effectively separates their aerodynamic behavior, ability to be inhaled, and efficacy of interventions.

Particles are exhaled in a continuum of sizes and they rapidly change size depending on their environment, e.g. due to evaporation (Lieber, Melekidis, Koch, \& Bauer, 2021). It is critical to understand the mechanisms of transport and deposition as a function of the size distribution of exhaled particles considering a range of external factors such as ventilation and air flows (Burridge et al., 2021). To that end, detailed experiments and models which accurately represent the relevant physics must be developed.

There is rapid advancement in approaches to modelling the fate of exhaled particles in different environments. These models have varying resolution and complexity in their representation of fluid flow and dispersion, and aerosol and droplet dynamics including evaporation, settling and transport(Chaudhuri, Basu, \& Saha, 2020; de Oliveira, Mesquita, Gkantonas, Giusti, \& Mastorakos, 2021; Shao et al., 2020; Wang, Wu, \& Wan, 2020).

As these modelling approaches evolve, it is essential to understand their robustness in representing the different physical processes. An important aspect of this is an objective inter-model comparison so that any differences in results can be attributed to alternative implementation of the physics or purposeful differences in modelled conditions. With this paper, we provide a consolidated set of parameters for exhalation of particles that can be used by a range of modelling approaches as the basis for model inter-comparison.

Droplets and aerosols produced by violent exhalation events, such as coughing and sneezing, have been investigated and reviewed by several studies (Bourouiba, 2020; Bourouiba, Dehandschoewercker, \& Bush, 2014; Mittal, Ni, \& Seo, 2020; Yang, Lee, Chen, Wu, \& Yu, 2007). Significant numbers of particles are also produced by breathing and speaking, activities which occur with 
greater frequency (Morawska et al., 2009). Under some circumstances, particularly in the case of presymptomatic or asymptomatic carriers who may not have symptoms of cough or sneezing, the cumulative amount of exhaled respiratory fluid as droplets and aerosols produced by high-frequency events such as breathing and speaking, may be greater than that due to low-frequency intermittent events (Dhand \& Li, 2020). Furthermore, there remains uncertainty as to the importance of cough symptoms to transmission, with a recent study finding no association and that viral load, rather than symptoms, might be the predominant driver of transmission (Marks et al., 2021). We therefore focus on defining parameters for breathing and speaking.

Details omitted from the main text are included in the Supporting Information (SI) where referenced.

\section{Model parameters and conditions}

The set of parameters which characterize exhalation of particles and environmental conditions relevant to particle transport are shown in Table 1.

\subsection{Exhalation}

Gupta, Lin, and Chen (2010) experimentally characterized various parameters associated with breathing and speaking; they measured gas flow rates, flow directions, and mouth and nose opening areas for 12 female and 13 male subjects. All subjects were healthy at the time of measurement and we note that there is a lack of literature on the potential effects of various symptoms of respiratory diseases on those parameters. The study documents significant variability amongst subjects and that flow rate is correlated to body surface area, which differs for males and females. The values listed in Table 1 represent nominal values for three cases of tidal (restful) breathing through the nose or mouth, and speaking.

Different models may have different requirements or constraints with regards to their representation of breathing. Breathing could be modelled as an unsteady phenomenon, or it may be more simplistically modelled as a constant flow rate. We have determined a self-consistent set of parameters for both approaches by conserving the total volume of exhaled air (and therefore the total number of exhaled particles). However, we note that this leads to different flow velocities at the mouth or nose opening as exhalation only occurs for approximately half of the breathing period.

The breathing air flow rate $\left(Q ;\left[\mathrm{L} \mathrm{s}^{-1}\right]\right)$ can be modelled by a sinusoidal function (Gupta et al., 2010),

$$
Q_{x}=a_{x} \sin \left(\beta_{x} t\right)
$$

where $t$ is time $\left[\mathrm{s}\right.$ ], the subscript $x$ indicates either inhalation (in) or exhalation (out), $\beta_{x}=\pi \mathrm{RF}_{x} / 30$ is a function of the respiratory frequency $\left(\mathrm{RF} ;\left[\mathrm{min}^{-1}\right]\right)$, and $a_{x}=\beta_{x} \mathrm{TV} / 2$. The RF for inhalation $\left(\mathrm{RF}_{\text {in }}\right)$ and exhalation $\left(\mathrm{RF}_{\text {out }}\right)$ are given as functions of body height $(H ;[\mathrm{cm}])$ and body mass $(W$; $[\mathrm{kg}]$ ) by equations 7-10 in Gupta et al. (2010) and shown in the SI §SI-1. The tidal volume (TV; $[\mathrm{L}])$ is given as 
medRxiv preprint doi: https://doi.org/10.1101/2022.02.11.22270844; this version posted February 15, 2022. The copyright holder for this preprint (which was not certified by peer review) is the author/funder, who has granted medRxiv a license to display the preprint in It is made available under a CC-BY-ND 4.0 International license.

Table 1: Parameters for modelling exhalation of particles.

\begin{tabular}{|c|c|c|c|c|}
\hline Parameter & Units & $\begin{array}{c}\text { Tidal } \\
\text { breathing } \\
\text { (nose) }\end{array}$ & $\begin{array}{c}\text { Tidal } \\
\text { breathing } \\
\text { (mouth) }\end{array}$ & Speaking \\
\hline \multicolumn{5}{|l|}{ Exhalation $(\S 2.1)$} \\
\hline Area of opening & $\mathrm{cm}^{2}$ & 0.71 & 1.20 & 1.80 \\
\hline Projection angle (side) & $\circ$ & $\theta_{\mathrm{n}, \mathrm{s}}=60$ & $\theta_{\mathrm{m}, \mathrm{s}}=0$ & $\theta_{\mathrm{m}, \mathrm{s}}=0$ \\
\hline Jet expansion angle (side) & $\circ$ & $\phi_{\mathrm{m}, \mathrm{s}}=23$ & $\phi_{\mathrm{m}, \mathrm{s}}=30$ & $\phi_{\mathrm{m}, \mathrm{s}}=30$ \\
\hline Projection angle (front) & $\circ$ & $\theta_{\mathrm{n}, \mathrm{f}}=69$ & - & - \\
\hline Jet expansion angle (front) & $\circ$ & $\phi_{\mathrm{n}, \mathrm{f}}=21$ & - & - \\
\hline Temperature & ${ }^{\circ} \mathrm{C}$ & 34 & 34 & 34 \\
\hline Relative humidity & $\%$ & 100 & 100 & 100 \\
\hline Source height & $\mathrm{m}$ & 1.5 & 1.5 & 1.5 \\
\hline Average flow rate & $\mathrm{L} \min ^{-1}$ & 10.6 & 10.6 & 12 \\
\hline \multicolumn{5}{|l|}{ Exhaled Particle Size Distribution $(\S 2.2)$} \\
\hline Mode 1: $\mathrm{GMD}_{1}$ & $\mu \mathrm{m}$ & 1.61 & 1.61 & 1.61 \\
\hline Mode 1: $\mathrm{GSD}_{1}$ & - & 1.30 & 1.30 & 1.30 \\
\hline Mode 1: $N_{1}$ & $\mathrm{~cm}^{-3}$ & 0.0540 & 0.0540 & 0.0540 \\
\hline Mode 2: $\mathrm{GMD}_{2}$ & $\mu \mathrm{m}$ & - & - & 2.40 \\
\hline Mode 2: $\mathrm{GSD}_{2}$ & - & - & - & 1.66 \\
\hline Mode 2: $N_{2}$ & $\mathrm{~cm}^{-3}$ & - & - & 0.0684 \\
\hline Mode 3: $\mathrm{GMD}_{3}$ & $\mu \mathrm{m}$ & - & - & 144.7 \\
\hline Mode 3: $\mathrm{GSD}_{3}$ & - & - & - & 1.8 \\
\hline Mode $3: N_{3}$ & $\mathrm{~cm}^{-3}$ & - & - & 0.00126 \\
\hline \multicolumn{5}{|l|}{ Exhaled Particle Composition ( $\$ 2.3)$} \\
\hline Composition: Salt, $\mathrm{NaCl}$ & $\mathrm{g} \mathrm{L}^{-1}$ & 9 & 9 & 9 \\
\hline Composition: Protein, BSA & $\mathrm{g} \mathrm{L}^{-1}$ & 3 & 3 & 3 \\
\hline Composition: Surfactant, DPPC & $\mathrm{g} \mathrm{L}^{-1}$ & 0.5 & 0.5 & 0.5 \\
\hline Molecular weight: $\mathrm{NaCl}$ & $\mathrm{g} \mathrm{mol}^{-1}$ & 58.4 & 58.4 & 58.4 \\
\hline Molecular weight: BSA & $\mathrm{g} \mathrm{mol}^{-1}$ & 66500 & 66500 & 66500 \\
\hline Molecular weight: DPPC & $\mathrm{g} \mathrm{mol}^{-1}$ & 734 & 734 & 734 \\
\hline Density: $\mathrm{NaCl}$ & $\mathrm{kg} \mathrm{m}^{-3}$ & 2160 & 2160 & 2160 \\
\hline Density: BSA & $\mathrm{kg} \mathrm{m}{ }^{-3}$ & 1362 & 1362 & 1362 \\
\hline Density: DPPC & $\mathrm{kg} \mathrm{m}^{-3}$ & 1082 & 1082 & 1082 \\
\hline \multicolumn{5}{|l|}{ Environmental conditions $(\S 2.4)$} \\
\hline Temperature & ${ }^{\circ} \mathrm{C}$ & 20 & 20 & 20 \\
\hline Pressure & atm & 1 & 1 & 1 \\
\hline Relative humidity & $\%$ & 40 & 40 & 40 \\
\hline
\end{tabular}


medRxiv preprint doi: https://doi.org/10.1101/2022.02.11.22270844; this version posted February 15, 2022. The copyright holder for this preprint (which was not certified by peer review) is the author/funder, who has granted medRxiv a license to display the preprint in

It is made available under a CC-BY-ND 4.0 International license.

$$
\mathrm{TV}=\frac{\mathrm{MV}\left(\mathrm{RF}_{\text {out }}+\mathrm{RF}_{\text {in }}\right)}{2 \mathrm{RF}_{\text {out }} \mathrm{RF}_{\text {in }}},
$$

where the minute volume ( $\mathrm{MV}$; $\left.\left[\mathrm{L} \mathrm{min}^{-1}\right]\right)$ is the volume of air exhaled in one minute (sometimes also referred to as the minute ventilation). The derivation of Eq. 2 is shown in the SI §SI-1. MV is correlated with the body surface area $\left(\mathrm{BSA} ;\left[\mathrm{m}^{2}\right]\right)$ by $\mathrm{MV}=c \times \mathrm{BSA}$. The constant $c$ ([L $\left.\mathrm{min}^{-1} \mathrm{~m}^{-2}\right]$ ) is 5.225 and 4.634 for males and females, respectively (Gupta et al., 2010). The BSA can be estimated according to Gehan and George (1970),

$$
\mathrm{BSA}=0.02350 H^{0.42246} W^{0.51456}
$$

where $H$ is height in $\mathrm{cm}$ and $W$ is body mass in $\mathrm{kg}$. Considering the average British male and female, who are 175.3 and $161.6 \mathrm{~cm}$ tall and weigh 83.6 and $70.2 \mathrm{~kg}$, respectively (Office for National Statistics, 2010), we obtain $a_{\text {in }}=0.5956, \beta_{\text {in }}=2.0629, a_{\text {out }}=0.5215$ and $\beta_{\text {out }}=1.8061$ for males and $a_{\text {in }}=0.0 .4794, \beta_{\text {in }}=1.6722, a_{\text {out }}=0.3991$ and $\beta_{\text {out }}=1.3922$ for females. Thus, the breathing flow rate $\left(Q_{\text {breathing }}\right.$; $\left.\left[\mathrm{L} \mathrm{s}^{-1}\right]\right)$ over the cycle of inhalation and exhalation can be represented by a piecewise sinusoidal function with a period of $\pi / \beta_{\text {in }}+\pi / \beta_{\text {out }}$,

$$
Q_{\text {breathing }}= \begin{cases}-a_{\text {in }} \sin \left(\beta_{\text {in }} t\right) & 0 \leq t \leq \pi / \beta_{\text {in }} \\ a_{\text {out }} \sin \left(\beta_{\text {out }}\left(t-\pi / \beta_{\text {in }}\right)\right) & \pi / \beta_{\text {in }}<t \leq\left(\pi / \beta_{\text {in }}+\pi / \beta_{\text {out }}\right) .\end{cases}
$$

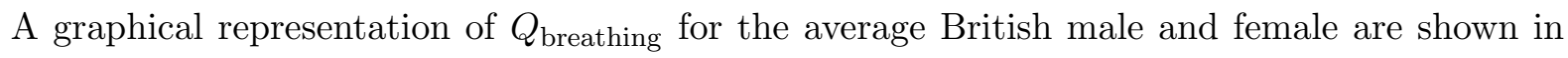
Figure 1. For the purposes of model comparison, we include $Q_{\text {breathing }}$ for the average British male in Table 1.

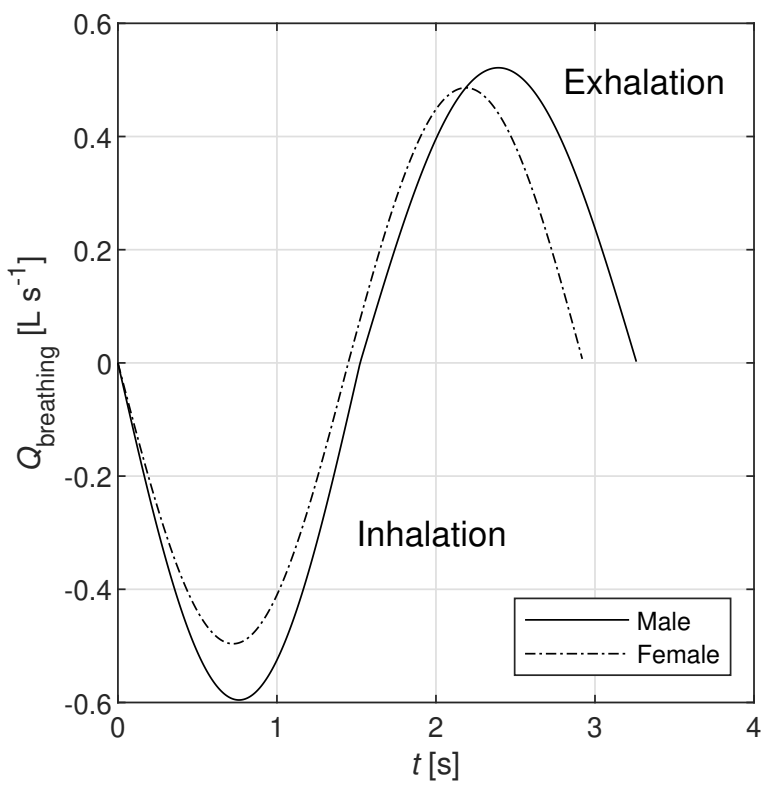

Figure 1: Graphical representation of the breathing flow rate.

Alternatively, the exhaled air flow rate may be modelled as a steady flow, in which case the average flow rate is obtained by dividing the total exhaled volume by the breathing period. Using 
medRxiv preprint doi: https://doi.org/10.1101/2022.02.11.22270844; this version posted February 15, 2022. The copyright holder for this preprint (which was not certified by peer review) is the author/funder, who has granted medRxiv a license to display the preprint in

It is made available under a CC-BY-ND 4.0 International license.

the same values of $a_{\text {out }}$ and $\beta_{\text {out }}$, we obtain an average exhalation flow rate of $10.6 \mathrm{~L} \mathrm{~min}^{-1}(0.177$ $\left.\mathrm{L} \mathrm{s}^{-1}\right)$ and $8.3 \mathrm{~L} \mathrm{~min}^{-1}\left(0.139 \mathrm{~L} \mathrm{~s}^{-1}\right)$ for the average male and female, respectively. These values are close to those recommended for representing breathing rates in risk assessments (Binkowitz \& Wartenberg, 2001).

For speaking, the breathing pattern is not sinusoidal and varies significantly with the vocalization. A nominal average exhalation flow rate is $12 \mathrm{~L} \mathrm{~min}{ }^{-1}\left(0.2 \mathrm{~L} \mathrm{~s}^{-1}\right)$ for vocalizing passages of text (Gupta et al., 2010). While this is adequate for model comparison, we encourage readers to study the original reference for values that may be more representative of specific cases and to other literature that has measured the spread of exhalation flow rates for different individuals and vocalisations, which suggest that exhalation flow rates during singing are similar to those during speaking (Jiang, Hanna, Willey, \& Rieves, 2016).

Nominal projection and spreading angles of the jets of exhaled air from the nose and mouth are also taken from Gupta et al. (2010) and they are shown graphically in Figure 2. For nose breathing, we suggest that it is appropriate to assume that the exhaled air flow is split equally between two nostrils. However we note that there is normally asymmetry in these flows due to anatomical, physiological and disease factors that shift and alternate the asymmetry over time (Hanif, Jawad, \& Eccles, 2000).

\section{Nose (front)}

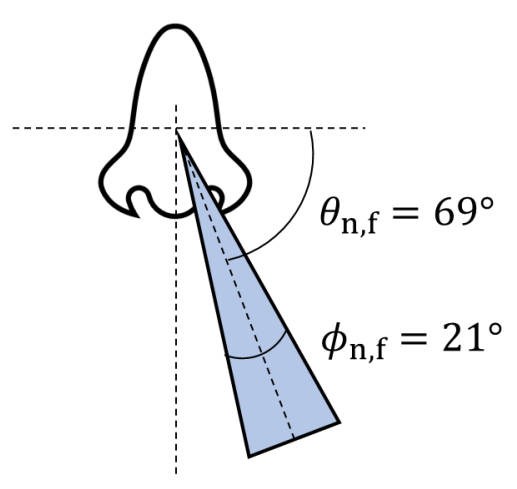

Nose (side)

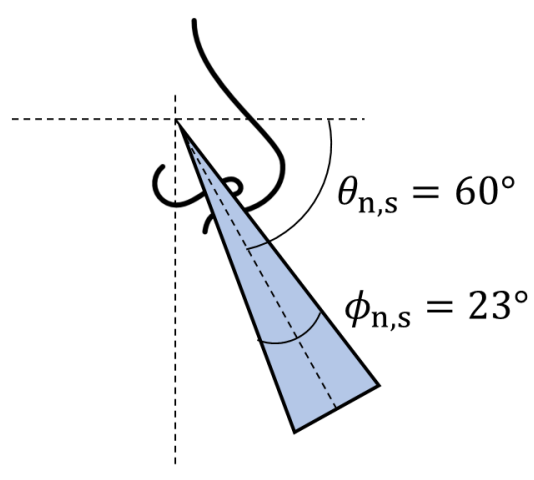

Mouth (side)

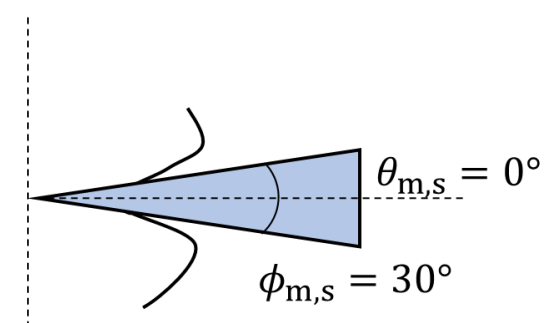

Figure 2: Graphical representation of jet projection $(\theta)$ and spreading $(\phi)$ angles.

\subsection{Exhaled particle size distribution}

The sizes of exhaled particles span several orders of magnitude and particle diameters range between $0.01-1000 \mu \mathrm{m}$ (Bake et al., 2019). The earliest measurements of exhaled particle sizes relied on the microscopic analysis of droplet marks on slides placed in front of the mouth (Duguid, 1946) and these techniques are still used to estimate exhaled particle counts for particle diameters $>10 \mu \mathrm{m}$ (Johnson et al., 2011; Xie, Li, Sun, \& Liu, 2009). Optical techniques have also been used to measure exhaled particles with diameters $>1 \mu \mathrm{m}$ (Alsved et al., 2020; Chao et al., 2009). In studies using the droplet deposition and microscopy methods, it is common for the total number of particles 
counted within different size ranges to be reported, rather than the concentration of particles in exhaled breath and corrections are typically applied to the measured particle size distribution to account for artefacts such as evaporation or spreading of the droplets on the surface of the slide. To measure particles of diameter $<10 \mu \mathrm{m}$, a number of studies have relied upon measurements using the aerodynamic particle sizer (APS, Model 3321, TSI Inc.), which has a manufacturer-specified particle aerodynamic diameter detection range of 0.5 to $20 \mu \mathrm{m}$ (Alsved et al., 2020; Asadi et al., 2019; Gregson et al., 2021; Johnson et al., 2011). These measurements are affected by the evaporation of water from the exhaled particles as they are expelled from the high humidity conditions in the body to the lower humidity of the experimental environment. The authors of these studies acknowledge that this process of droplet drying happens in the timescale of $\sim 1 \mathrm{~s}$ (Lieber et al., 2021) and that the measured size distribution is representative of the equilibrium size distribution. Johnson et al. (2011) applied a correction to account for the shrinkage of particles due to evaporation, whereas other studies have chosen not to correct for this process. Another important distinction between studies measuring particles in this size range is studies have either sampled a small fraction of the exhaled air flow (Asadi et al., 2019; Gregson et al., 2021) or have sampled the plume of exhaled air and corrected the measured concentration for plume dilution, as measured using a trace gas (e.g. water) (Johnson et al., 2011). A comparison of particle size distributions from different studies is shown in Figure 3 and details of the source of data for this plot can be found in the SI §SI-2.

Johnson et al. (2011) reported that particles generated from breathing, speaking and coughing were present in a range of sizes, represented by distinct modes of a frequency distribution of particle diameters that spans from 0.1 to $1000 \mu \mathrm{m}$. They propose the BLO model for the size distribution of particles measured: bronchiolar $(B)$, laryngeal $(L)$ and oral $(O)$ to represent the different locations in the airways believed to be the source of the aerosols.

A recent publication showed that patients admitted to hospital with COVID-19 exhaled similar aerosol size distributions to healthy patients when breathing, speaking and coughing (Hamilton et al., 2021).

\section{Bronchiolar and laryngeal particles}

Particle diameters from the first two modes, bronchiolar and laryngeal, were found to range from at least 0.5 to $5 \mu \mathrm{m}$, both with median diameters of order $1 \mu \mathrm{m}$ using on-line measurement techniques using the APS and after correction for evaporation by assuming a shrinkage factor of 0.5 (Johnson et al., 2011). The evaporation-corrected size distribution represents the initial particle size distribution at the mouth and can be compared to the uncorrected equilibrium size distribution in Figure 3. Recently, Asadi et al. (2019) and Gregson et al. (2021) reported equilibrium particle size distributions for breathing and speaking. For speaking, both studies report significant variability with respect to the loudness of vocalisation and amongst individuals. As shown in Figure 3, these two studies are in good agreement with the uncorrected size distribution from Johnson et al. (2011) with respect to median diameters. However, the three studies span approximately an order of magnitude in concentration and the size distributions from Asadi et al. (2019) and Gregson et al. (2021) appear to have a larger spread (i.e. geometric standard deviation). The difference in concentration between studies is likely within the range of variation due to vocalization, loudness and individual variability, however it is possible that sampling and data processing differences may also contribute.

While we focus here on breathing and speaking, we acknowledge that there are recent studies 

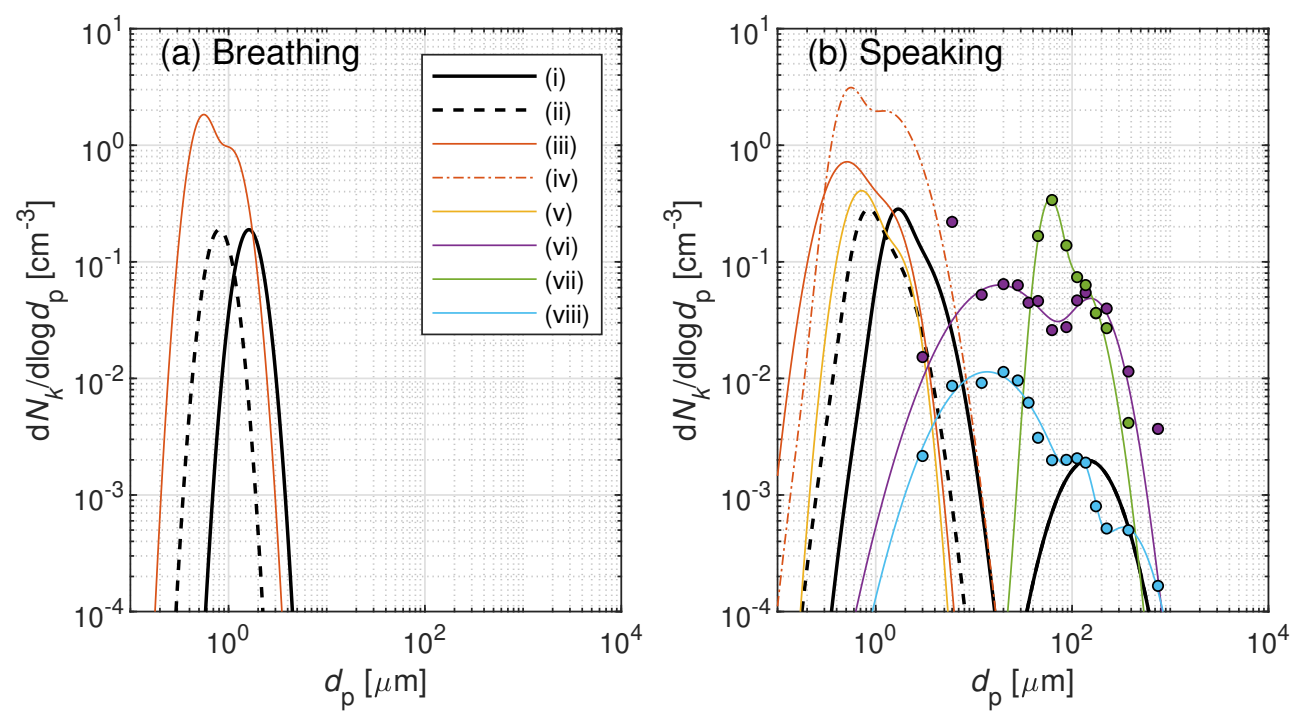

Figure 3: Exhaled particle size distributions resulting from (a) breathing and (b) speaking from (i) Johnson et al. (2011) corrected for particle shrinkage and representing the PSD at the mouth (BLO model), (ii) Johnson et al. (2011) not corrected for particle shrinkage (iii) Gregson et al. (2021) (70-80 dBA in (b)), (iv) Gregson et al. (2021) (90-100 dBA in (b)), (v) Asadi et al. (2019) (Fig. S10), (vi) Chao et al. (2009), (vii) Xie et al. (2009) and (viii) Duguid (1946). Parameters of lognormal distributions and further information on the sources of data are included in the SI §SI-2.

reporting particle size distributions for singing (Alsved et al., 2020; Gregson et al., 2021). While singing is found to increase the number concentration of exhaled particles relative to speaking, the increase is small relative to the changes associated with increased loudness (Gregson et al., 2021).

\section{Oral particles}

Johnson et al. (2011) reported that the oral mode of particles measured during speaking were larger than $10 \mu \mathrm{m}$ in diameter and all contained food-dyed saliva, demonstrating that those particles originated from the mouth. This observation of the presence of food-dye is in agreement with Duguid (1946) and Xie et al. (2009), and data from these two studies are also shown in Figure 3. We have also included the optical measurements from Chao et al. (2009) in Figure 3 and it is evident that there is significant variation in the magnitude, mode and spread of size distributions for oral particles. These differences may be attributed to differences in measurement techniques, vocalizations and variability amongst individuals. It is beyond the scope of this paper to review these differences in detail, however we note the need for further studies that compare different measurement approaches, for example by conducting simultaneous measurements using different techniques of the same exhaled aerosol, and the interested reader is referred to the following additional references (Almstrand et al., 2010; Loudon \& Roberts, 1967; Papineni \& Rosenthal, 1997; Stadnytskyi, Bax, Bax, \& Anfinrud, 2020). We recommend that the oral particle size distribution for speaking is treated as more uncertain than the bronchiolar and laryngeal modes. The parameters for the size distributions from different studies are included in the SI §SI-2 to enable model sensitivity studies. There is limited evidence of exhaled aerosols with diameters $>10 \mu \mathrm{m}$ as a result of singing. 


\section{Parameter specification}

The discussion above indicates that there is significant variability in exhaled particle concentration and size distribution due to respiratory activity and individual variability. For the purposes of model comparison, we adopt the BLO model (Johnson et al., 2011), corrected to represent the particle size distribution at the mouth (series (i) in Figure 3), as the basis of the terms included in Table 1. We note that this particle size distribution is representative of the mean for the group of healthy volunteers in that study and is therefore not predictive of a single person as inter- and intra-person variability is of the order of measured concentration itself or greater (Johnson et al., 2011).

For breathing, only the $B$ mode is included. For speaking, the size distribution of exhaled particles is the sum of the three $B, L$ and $O$ lognormal distribution modes (Johnson et al., 2011),

$$
\frac{\mathrm{d} N_{k}}{\mathrm{~d} \log d_{\mathrm{p}}}=\ln (10) \sum_{i=1}^{3}\left[\left(\frac{N_{i}}{\sqrt{2 \pi} \ln \left(\mathrm{GSD}_{i}\right)}\right) \exp \left(-\frac{\left(\ln d_{\mathrm{p}}-\ln \mathrm{GMD}_{i}\right)^{2}}{2\left(\ln \mathrm{GSD}_{i}\right)^{2}}\right)\right],
$$

where $d_{\mathrm{p}}$ is the particle diameter $[\mu \mathrm{m}], N_{i}$ is the total number concentration $\left[\mathrm{cm}^{-3}\right]$ of each mode $i, \mathrm{GMD}_{i}$ is the geometric mean diameter $[\mathrm{\mu m}]$ of each mode $i$, and $\mathrm{GSD}_{i}$ is the geometric standard deviation of each mode $i$. Each mode may be characterized by only three parameters: GSD $_{i}$, $\operatorname{GMD}_{i}$, and $N_{i}$ as given in Table 1. The particle size distribution for breathing and speaking is shown in Figure 4(a).

The notation $\mathrm{d} N_{k} / \mathrm{d} \log d_{\mathrm{p}}$ represents the number concentration in each bin of particle diameters $\left(\mathrm{d} N_{k}\right)$ normalized by a bin width that is constant in $\log$ space, i.e. $\mathrm{d} \log d_{\mathrm{p}}=\log \left(d_{\mathrm{p}, k+1} / d_{\mathrm{p}, k}\right)$, where $k$ represents a discretization of the $d_{\mathrm{p}}$ space. Note that log here refers to the base 10 logarithm and Eq. 5 is preserved from Johnson et al. (2011). Therefore, the absolute number concentration of particles of a given bin of particle diameters $\left(\mathrm{d} N_{k} ;\left[\mathrm{cm}^{-3}\right]\right)$ is calculated as,

$$
\mathrm{d} N_{k}=\frac{\mathrm{d} N_{k}}{\mathrm{~d} \log d_{\mathrm{p}}} \mathrm{d} \log d_{\mathrm{p}}
$$

In the context of exhalation, it is important to consider both number and volume of exhaled particles. The volume of particles of a given diameter represented as a concentration $\left[\mathrm{\mu m}^{3} \mathrm{~cm}^{-3}\right]$, assuming all particles are spherical, is given by

$$
\mathrm{d} V_{k}=\frac{\mathrm{d} V_{k}}{\mathrm{~d} \log d_{\mathrm{p}}} \mathrm{d} \log d_{\mathrm{p}}=\mathrm{d} N_{k}\left(\pi d_{\mathrm{p}, k}^{3} / 6\right)
$$

The volume weighted particle size distribution and cumulative number and volume fractions are shown in Figure 4(b-d) for breathing and speaking. The total number concentration, $N$, of particles is $0.054 \mathrm{~cm}^{-3}$ for breathing and $0.1237 \mathrm{~cm}^{-3}$ for speaking and the total volume concentration, $V$,

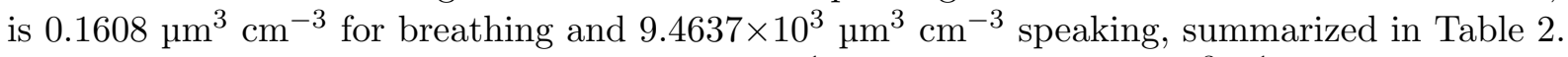

The release rate of particle number $\left(E_{N, k} ;\left[\mathrm{s}^{-1}\right]\right)$ or volume $\left(E_{V, k} ;\left[\mathrm{um}^{3} \mathrm{~s}^{-1}\right]\right)$ for a given particle diameter is calculated as the product of the particle number or volume concentration and the exhaled flow rate, i.e.

$$
\begin{aligned}
& E_{N, k}=\mathrm{d} N_{k} \max \left[0, Q_{\text {breathing }}\right] \\
& E_{V, k}=\mathrm{d} V_{k} \max \left[0, Q_{\text {breathing }}\right] .
\end{aligned}
$$



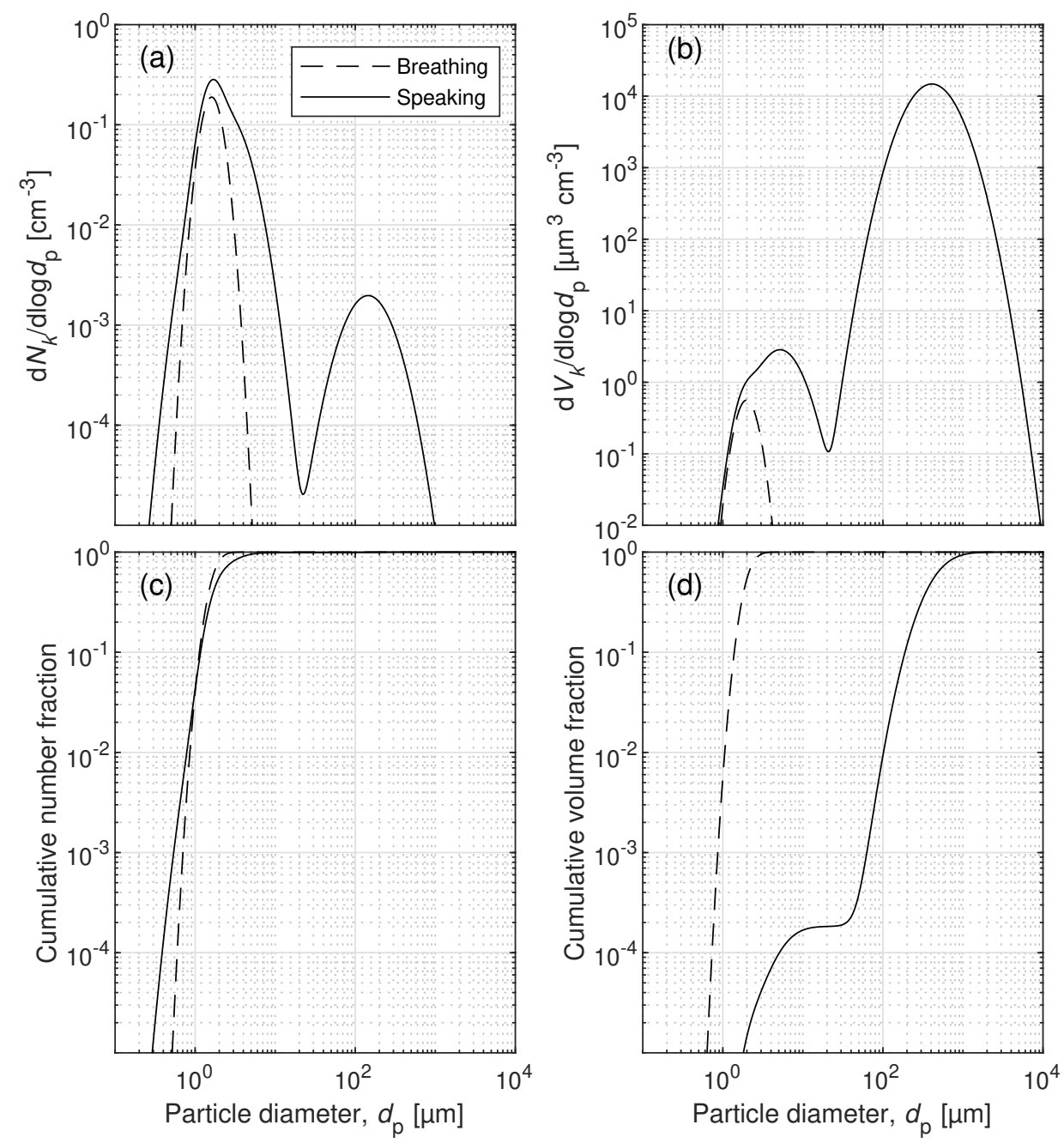

Figure 4: (a) Number and (b) volume weighted particle size distributions, and cumulative fractions of (c) particle number and (d) volume as a function of particle diameter for breathing and speaking.

For example, considering a nominal average flow rate of $12 \mathrm{~L} \mathrm{~min}-1\left(200 \mathrm{~cm}^{3} \mathrm{~s}^{-1}\right)$ for vocalizing passages of text (Gupta et al., 2010) and exhaled number, $N$, and volume, $V$, concentrations for

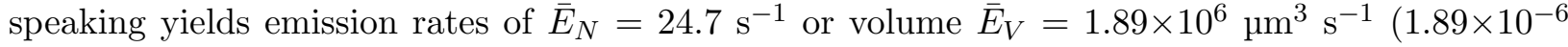
$\left.\mathrm{mL} \mathrm{s}^{-1}\right)$. Estimates of particle emission rates during breathing and speaking are summarized in Table 2, highlighting that speaking produces an estimated $6.7 \times 10^{4}$ times larger volume of fluid than breathing alone, primarily from the oral mode of droplets (typically larger than 10-50 $\mathrm{mm}$ ) originating from the mouth.

\subsection{Exhaled particle composition}

Exhaled particles are multi-component droplets comprising water, salts, proteins and surfactants (Effros et al., 2002; Vejerano \& Marr, 2018; Veldhuizen \& Haagsman, 2000). Once exhaled from the nose or mouth, these particles are exposed to a rapidly changing relative humidity $(\mathrm{RH})$ within the 
Table 2: Estimates of concentrations and emission rates of particles.

\begin{tabular}{lccc}
\hline Parameter & Units & Breathing & Speaking \\
\hline Nominal average flow rate: $\bar{Q}$ & $\mathrm{~cm}^{3} \mathrm{~s}^{-1}$ & 176 & 200 \\
Exhaled number concentration: $N$ & $\mathrm{~cm}^{-3}$ & 0.054 & 0.124 \\
Exhaled volume concentration: $V$ & ${\mu \mathrm{m}^{3} \mathrm{~cm}^{-3}}$ & 0.161 & $9.46 \times 10^{3}$ \\
& $\left(\mathrm{~mL} \mathrm{~cm}^{-3}\right)$ & $\left(1.61 \times 10^{-13}\right)$ & $\left(9.46 \times 10^{-9}\right)$ \\
Avg. number emission rate: $\bar{E}_{N}$ & $\mathrm{~s}^{-1}$ & 9.50 & 24.7 \\
Avg. volume emission rate: $\bar{E}_{V}$ & $\mathrm{\mu m}^{3} \mathrm{~s}^{-1}$ & 28.3 & $1.89 \times 10^{6}$ \\
& $\left(\mathrm{~mL} \mathrm{~s}^{-1}\right)$ & $\left(2.83 \times 10^{-11}\right)$ & $\left(1.89 \times 10^{-6}\right)$ \\
\hline
\end{tabular}

exhaled breath from approximately $100 \%$ to ambient conditions. The combination of the droplet composition and ambient temperature and relative humidity will influence the evaporation rate and therefore affect settling times of a single respiratory droplet (Lieber et al., 2021; Marr, Tang, Van Mullekom, \& Lakdawala, 2019; Walker et al., 2021). As a multi-component droplet with nonvolatile solutes evaporates, the evaporation rate may change throughout the process due to an increase in concentration of solutes in the liquid, as well as other physico-chemical transformations (Vejerano \& Marr, 2018). The resulting size of the droplet, represented by a characteristic diameter, after it has come into equilibrium with the ambient conditions not only determines its settling time (de Oliveira et al., 2021; Marr et al., 2019; Walker et al., 2021; Xie et al., 2009), but also its fate in the respiratory system should it be inhaled by an individual (ICRP, 1994; Madas et al., 2020; Milton, 2020). When considering the whole range of sizes found in respiratory releases (Fig. 4), the combined effect of relative humidity and composition may result in up to an order-of-magnitude difference in the total amount of suspended mass of a droplet cloud of different compositions (de Oliveira et al., 2021).

For the purposes of model comparison, we suggest a four-component droplet composition consisting of $9 \mathrm{mg} \mathrm{mL}^{-1}$ of NaCl, $3 \mathrm{mg} \mathrm{mL}^{-1}$ of protein (bovine serum albumin, BSA), and $0.5 \mathrm{mg}$ $\mathrm{mL}^{-1}$ of surfactant (dipalmitoylphosphatidylcholine, DPPC) in water. This protein concentration is representative of the composition of nasal surface airway fluid (Gould \& Weiser, 2001) and this simplified composition is comparable to concentrations in simulated lung fluid (Hassoun, Royall, Parry, Harvey, \& Forbes, 2018; Kumar et al., 2017; Walker et al., 2021), and has been used in a previous modelling study (de Oliveira et al., 2021). The concentration of each component, together with their respective molecular weight and density (Haynes, 2013; Nagle \& Wilkinson, 1978; NCBI, 2020; Tanford, 1961) are given in Table 1. Properties of water for modelling the dynamics of particles including evaporation are readily available from e.g. Green and Perry (2019). The three other components (i.e. $\mathrm{NaCl}$, protein, and surfactant) are not volatile at typical ambient conditions due to their significantly higher molecular weights and melting points (ChemSpider, 2020; Michnik, 2003). We note that when modelling the dispersal of virus within respiratory fluid (c.f. §3), the contribution of virus particles to the bulk composition of the particle is negligible for typical viral loads.

\subsection{Environmental conditions}

The temperature and relative humidity of ambient air significantly affects the fate of exhaled particles, in terms of the rate of evaporation of water from droplets (de Oliveira et al., 2021; Redrow, Mao, Celik, Posada, \& Feng, 2011), and, while not not explicitly relevant to defining 
source terms, the inactivation rates of enveloped viruses (K. Lin \& Marr, 2020; Marr et al., 2019; Morris et al., 2021).

Guidelines for different indoor environments are published by various regulatory bodies. For example, guidelines for ward spaces and intensive care units in hospitals, set design air temperature and relative humidity ranges between $20-24^{\circ} \mathrm{C}$ and $30-60 \%$, respectively (Beggs, Kerr, Noakes, Hathway, \& Sleigh, 2008) and similar guidelines exist for schools in different countries (Education and Skills Funding Agency (ESFA), 2018; Mohamed, Rodrigues, Omer, \& Calautit, 2021; S, E, Y, \& E, 2014).

Empirical studies on indoor temperature and relative humidity in different environments suggest that these can vary with the seasons and that there is variability between buildings used for the same purpose. In three hospitals in the US, temperatures were measured to within the recommended range of $20-24^{\circ} \mathrm{C}$, however relative humidity was consistently below $40 \%$ in all locations (Quraishi, Berra, \& Nozari, 2020). In two hospitals in France, average temperatures and humidity ranged from $19-27^{\circ} \mathrm{C}$ and $16-70 \%$, respectively, across all seasons (Baurès et al., 2018). For low-income households in the UK in winter, median indoor temperature and relative humidity were found to be $19^{\circ} \mathrm{C}$ [14-23 ${ }^{\circ} \mathrm{C}$, 5th to 95th centile range] and $43 \%$ [32-60\%] in living rooms, respectively (Oreszczyn, Ridley, Hong, Wilkinson, \& Group, 2006), with significant variability by season and dwelling type (McGill, Oyedele, \& McAllister, 2015). For dwellings in the US, median indoor temperature and relative humidity were found to be $20^{\circ} \mathrm{C}\left[18-27^{\circ} \mathrm{C}\right.$, range $]$ and $48 \%$ [23-71\%], with seasonal variations in relative humidity (Nguyen, Schwartz, \& Dockery, 2014). In industrial settings, there may be indoor conditions that are specific to the activity and setting, e.g. meat processing (Günther et al., 2020), and standards and outdoor conditions will have an effect in different climatic regions (De Vecchi, Candido, de Dear, \& Lamberts, 2017; Wu, Cao, \& Zhu, 2018).

The empirical evidence suggest that temperature and relative humidity span the range of 20$24^{\circ} \mathrm{C}$ and $30-60 \%$, respectively. For model comparison we propose an ambient temperature of $20^{\circ} \mathrm{C}$ and a relative humidity of $40 \%$, which are included in Table 1. Given the importance of these parameters, we would encourage researchers to present results for the ranges of $15-30^{\circ} \mathrm{C}$ and $30-60 \%$, as a minimum.

\section{Pathogens in exhaled particles}

There is limited evidence for the amounts of pathogens possibly contained in particles exhaled by different respiratory activities and significant variability among different types of pathogens, therefore we do not include values for concentrations of pathogens in our set of parameters for exhaled particles. However, considering the recent focus on modelling transmission of SARS-CoV2 , below we discuss the data for SARS-CoV-2 to help readers make more informed judgments on appropriate viral load values for their modelling efforts.

\subsection{Prevalence of SARS-CoV-2 in indoor air}

At the time of writing, the viral load and infectivity of SARS-CoV-2 in exhaled particles of different sizes has not been well established (Dabisch et al., 2020). Gene copies ${ }^{1}$ of SARS-CoV-2 ribonucleic

\footnotetext{
${ }^{1}$ Studies commonly report gene copies of a target gene (e.g. N gene of SARS-CoV-2) which are converted from cycle thresholds $(\mathrm{Ct})$ by calibration for a given PCR system. Cycle thresholds represent the number of amplification
} 
acid (RNA) have been detected by polymerase chain reaction (PCR) analyses of samples of indoor air gathered in a range of (mostly clinical) settings (Zhang \& Duchaine, 2020), including in aerosols smaller than 5 um (Chia et al., 2020; Feng et al., 2021; Liu et al., 2020). In indoor air, the concentrations of SARS-CoV-2 RNA reported in particles smaller than $5 \mu \mathrm{m}$ are of order $1 \times 10^{-5}$ (Liu et al., 2020) to $1 \times 10^{-3}$ (Chia et al., 2020; Feng et al., 2021; Ong et al., 2021) gene copies per $\mathrm{cm}^{3}$ of sampled air.

Importantly, modellers must note that the number of SARS-CoV-2 gene copies detected by PCR quantifies sub-sections of the viral RNA sequence and is therefore not equal to the number of infectious viruses present. However, based on a range of clinical samples (e.g. nasopharyngeal swabs), the likelihood of detecting infectious SARS-CoV-2 by viral culture methods is correlated with number of gene copies reported where RNA viral loads greater than $10^{5}-10^{6}$ gene copies $/ \mathrm{mL}$ (corresponding to $\mathrm{Ct}<\sim 24-25)$ and higher are typically required to demonstrate infectivity of a clinical sample containing SARS-CoV-2 (Bullard et al., 2020; Cevik et al., 2021; Huang et al., 2020; Kim et al., 2021; Y.-C. Lin et al., 2021; Singanayagam et al., 2020; van Kampen et al., 2021; Wölfel et al., 2020). To date, cycle thresholds for the air samples that detect SARS-CoV-2 RNA are very often $>30$ and even $>35$, implying air samples are often not likely to culture (Zhang \& Duchaine, 2020). Of attempts to demonstrate the infectivity of SARS-CoV-2 suspended in field samples of indoor air by viral culture methods (Döhla et al., 2020; Ong et al., 2021; Santarpia et al., 2020; Yamagishi et al., 2020; J. Zhou et al., 2020), there has been limited evidence of viral replication or cytopathic effects (CPE) (Lednicky et al., 2020, 2021; Santarpia et al., 2020).

Plaque assay, a cell culture method, when performed on samples with higher viral loads than typically found in air samples (e.g. naso-pharyngeal swabs), enables quantification of the number of infectious viruses capable of forming plaques in a cell monolayer, called plaque forming units (PFU). These PFUs may be used in dose-response models to estimate infection risk in humans (as done for SARS, for example (Watanabe, Bartrand, Weir, Omura, \& Haas, 2010)). Syrian hamsters inoculated by the intranasal route were infected with a dose of as low as 14 PFUs and the minimum infectious dose may be lower in humans (Y.-C. Lin et al., 2021). Since there is insufficient data on the possible load of infectious viruses in air samples, it is appropriate to estimate a possible range based on the number of gene copies detected. A ratio of RNA gene copies (N Gene) to PFUs of $\sim 160,000: 1$ was found using almost 500 clinical samples (including naso-pharyngeal swabs, sputum, saliva, and fomites) from 75 patients. A ratio of 10,000:1 was reported when using a more homogeneous virus that can be harvested from culture in a laboratory setting (Y.-C. Lin et al., 2021), in line with other studies (Plante et al., 2021). Therefore, roughly assuming an RNA:PFU ratio of 10,000:1, air concentrations of $1 \times 10^{-3}$ (Chia et al., 2020; Feng et al., 2021; Ong et al., 2021 ) gene copies per $\mathrm{cm}^{3}$ of sampled air would correspond to $1 \times 10^{-7} \mathrm{PFU}$ per $\mathrm{cm}^{3}$ of air (or one $\mathrm{PFU}$ in ten cubic meters of air). Measurements of viral prevalence in indoor air includes many variables depending on the situation. To model viral exhalations, it is preferred to use empirical data from direct measurements of viruses contained in exhaled air, or data of viral load contained in the respiratory tract fluid that is exhaled.

cycles used to detect a target gene by PCR, where lower Ct values correspond to higher numbers of gene copies. Since $\mathrm{Ct}$ are platform dependent, it is preferred to compare among studies using gene copies determined by a standard calibration procedure. 


\subsection{Prevalence of SARS-CoV-2 in air directly exhaled by infected persons}

SARS-CoV-2 RNA has been detected in exhaled breath condensate (EBC), where participants' exhaled breath is cooled and its contents are condensed into solution for analysis, without resolving the exhaled particle size distribution (Ding et al., 2021; Feng et al., 2021; Ma et al., 2020; Ryan et al., 2021; L. Zhou et al., 2021). Some studies report that concentrations in excess of $\sim 10^{-1}$ gene copies per $\mathrm{cm}^{3}$ of exhaled breath are possible, calculated based on their PCR results for EBC and the volume of air sampled (Ma et al., 2020; L. Zhou et al., 2021). Recent studies use a sampling apparatus which separates bioaerosols into 'coarse' $(>5 \mu \mathrm{m})$ and 'fine' $(\leq 5 \mu \mathrm{m})$ fractions to compare exhalations from breathing, speaking and coughing (Coleman et al., 2021) or assess the performance of masks (Adenaiye et al., 2021) for the amount of SARS-CoV-2 exhaled. These studies report significantly lower RNA exhalation rates than Ma et al. (2020) reported for EBC. More data of direct measurements of exhalations are needed to provide more confidence in models of virus exhalations, however these studies provide insights to quantify virus exhalaton rates (Adenaiye et al., 2021; Coleman et al., 2021).

Studies haven't yet attempted to quantify indoor air samples relative to exhaled breath samples for the same participants, and comparisons between studies are subject to variabilities in viral load of patient, variant type, room air ventilation rates (and, designed vs actual ventilation rates), variance in expiration rates based on patient (e.g. patient coughing vs breathing). A value of $10^{-3}$ gene copies per $\mathrm{cm}^{3}$ for room air (Chia et al., 2020; Feng et al., 2021; Ong et al., 2021) and $10^{-1}$ gene copies per $\mathrm{cm}^{3}$ for exhaled breath (Ma et al., 2020; L. Zhou et al., 2021) would suggest a reasonable dilution ratio of 100 , but this relation may be coincidental and more systematic sampling is required.

\subsection{Prevalence of pathogens in respiratory fluid}

Caution must be exercised if estimating viral load from samples of fluid extracted directly from the respiratory tract (e.g. naso-pharyngeal swabs). Aerosols are plausibly generated from small airways (Johnson \& Morawska, 2009; Malashenko, Tsuda, \& Haber, 2009), airway walls (Moriarty \& Grotberg, 1999), larynx (Johnson \& Morawska, 2009), and mucosalivary fluid from the mouth (Bourouiba, 2021a; Johnson et al., 2011) by a range of mechanisms. Measurements of viral load in respiratory fluid span several orders of magnitude, they change over the course of the disease and they can be different depending on the source of respiratory fluid (Singanayagam et al., 2020; Walsh et al., 2020; Wölfel et al., 2020).

To date, many studies have assumed a constant concentration of viruses in the fluid that composes the exhaled particles across the continuum of particle sizes (Stadnytskyi et al., 2020) to assess relative risk rather than absolute risk of disease transmission associated with the modelled scenarios. Given that assumption, considering the cumulative volume fractions in Figure 4 show the vast majority of respiratory fluid by volume is in the oral mode, it is expected the vast majority of viral RNA detected would be found in the oral mode. However, recent data from the studies discussed in Section 3.2 question this assumption. Coleman et al. (2021) reported from direct measurements of breathing, speaking and coughing, that $85 \%$ of the detected RNA copies were found in the fine $(\leq 5 \mu \mathrm{m})$ aerosol fraction compared with the coarse $(>5 \mu \mathrm{m})$ aerosol fraction. Comparable results, where similar or more viral RNA is found in the fine aerosol mode, have been found for influenza (Leung et al., 2020; Milton, Fabian, Cowling, Grantham, \& McDevitt, 2013; Yan et al., 2018), and these results have substantial implications for the relative importance of short versus 
long range transmission. However, the viral RNA possibly carried by the largest droplets may not be detected if they, for example, drop into the walls of the cone of the Gesundheit-II apparatus used in Coleman et al. (2021) and are not retrieved. Cheng et al. (2021) discussed the discrepancy between measurements of viral exhalations with other measurements of aerosol/droplet volumes as a function of particle size citing a possible gradient in viral load throughout the respiratory tract.

In light of this recent evidence, in the SI §SI-3 we propose a method for scaling a viral load in the $\mathrm{B}$ and $\mathrm{L}$ modes relative to the $\mathrm{O}$ mode of the exhaled particles so that researchers can test their models in the limit where viral load in fine aerosols is significantly higher. We present this in general terms such numerical values can be updated as more evidence becomes available. Taking the measurements from Coleman et al. (2021), where $85 \%$ of the viral load to be in the particles with diameter less than $5 \mathrm{\mu m}$, we calculate that the viral load in the B and L modes would need to be $6 \times 10^{5}$ times higher than the viral load in the $\mathrm{O}$ mode.

There is a critical need improve the empirical data for the viral load in different particle sizes. Evidence from swab samples reported by Tu et al. (2020) showed tongue swabs, perhaps representing the oral mode, contained generally lower viral RNA loads than NP swabs, perhaps representing the B and L models, though by 1-2 orders of magnitude, not 4-5.

\section{Correcting conversions for volumes of respiratory fluid}

We do not recommend directly using clinical data of gene copies per $\mathrm{mL}$ reported for swab samples that have been diluted into another fluid. For example, naso-pharyngeal swab samples are submerged and transported in viral transport media (typically in $3 \mathrm{~mL}$ of transport media) (Wölfel et al., 2020). Subsequent measurements of viral RNA by PCR could be reported in gene copies per mL of transport media or gene copies per swab. However, the exact volume of respiratory fluid sampled on a given swab is unknown. While this is roughly of order $0.1 \mathrm{~mL}$, the volume collected depends on the type of swab, practitioner and properties of the fluid. The dilution correction is therefore not well known and furthermore elution of viruses from the swab may be incomplete (Warnke, Warning, \& Podbielski, 2014). More discussion may be found in Roque et al. (2021) which points out that if the average NP swab collects and releases $50 \mu \mathrm{L}$ of nasal secretions and is stored $3 \mathrm{~mL}$ of transport media, the original sample is diluted 60:1. Then, volumes extracted from the total solution for analyses by PCR must be correctly accounted. These conversions may be estimated for modelling purposes, however it must again be noted that the viral load may be different in different regions of the respiratory tract.

\subsection{Experimental data needed for estimation of viral loads in aerosols and droplets}

There are significant complexities of gathering experimental data relevant to disease transmission. Considering only aerosol sampling, it is difficult to gather size-resolved measurements of viral load in a controlled manner. For particle diameters larger than $\sim 10 \mu \mathrm{m}$, competing transport phenomena (e.g. convection, gravity, inertial impaction) affect sampling, which may introduce bias in the reported results. Depending on the bioaerosol sampling method, the range of particle sizes sampled must be carefully considered. For example, the smallest particles $<0.3 \mu \mathrm{m}$ are inefficiently captured in a BioSampler (Lindsley et al., 2017). Furthermore, for there to be an infection risk, the pathogen must be viable at the time of exhalation and must survive in the exhaled aerosol particles or droplets. The survival of viruses and bacteria in aerosols and droplets is highly dependent on the 
environmental conditions, such as the relative humidity, temperature and exposure to light (Dabisch et al., 2020; K. Lin \& Marr, 2020; Marr et al., 2019). Therefore, it is critical that both gene copies and attempts to culture the virus are reported in measurements along with resolution of viral load as a function of particle size.

Additionally, more measurements of exhaled particle size distributions are needed. Specifically, since the particle sizes emitted vary by several orders of magnitude $(\sim 0.01-1000 \mu \mathrm{m})$, more data are needed from instruments which complement one another to capture the entire size ranges of aerosols and droplets for the same exhalatory activities (Bourouiba, 2021b). These data which are available in a controlled setting are critical to reconcile with viral exhalation rates described above, which are arguably more difficult to gather. By combining data of viral exhalations and aerosol/droplet exhalations, more accurate assessments of relative risk of different modes of transmission in specific scenarios are possible.

\section{Summary and recommendations}

There is rapid advancement in approaches to modelling the fate of exhaled particles in different environments. As these modelling approaches evolve, it is important that each model implementation can be verified by comparison with others, and that any differences in results can be attributed to incomplete specification or alternative implementation of the physics. With this paper, we provide a consolidated set of parameters for exhalation of particles that are appropriate to be used by a range of modelling approaches as the basis for model inter-comparison and benchmarking.

In reporting results, details of all physical and mathematical models should be provided along with a description of the modelled scenario including a diagram, dimensions, and all boundary conditions. It is necessary to resolve particle transport (and deposition) as a function of particle diameter, therefore distributions of both number concentrations and volume concentrations (as shown in Figure 4) should be reported as a function of time and spatial location relative to the particle source (e.g. in vertical and horizontal cross sections). By reporting distributions of particles by volume, models for viral load within each particle may be readily applied to model virus dispersal and deposition, allowing relative assessments of risk relative rather than absolute assessments of risk.

While this paper focuses on defining a set of terms for model benchmarking, there is significant person-to-person variability in exhaled air flows, exhaled particle distributions and composition, and, perhaps most significantly, in viral load. The evidence base for the statistical distribution of these parameters within the population is incomplete; different studies typically have small sample sizes and are not often directly comparable, for example due to different vocal activities and measurement methods. Thus, there is insufficient evidence to quantify the modal, mean or median parameter values within the population. We therefore strongly encourage modelers to account for the sensitivity of their results to these uncertainties: exhaled air flow variability could be quantified using distributions of body height and weight (Gupta et al., 2010; Jiang et al., 2016); a number of different measured exhaled aerosol distributions are presented in the SI §SI-3; different representations of respiratory droplet composition could be used (Edwards et al., 2021; Vejerano \& Marr, 2018; Walker et al., 2021); and, the large range in viral load discussed in Section 3 must be accounted for in any attempt to quantify the absolute risk of transmission.

There remain a significant number of outstanding questions related to airborne transmission of pathogens. Modelling the fate of exhaled particles, when implemented with careful verification of 
medRxiv preprint doi: https://doi.org/10.1101/2022.02.11.22270844; this version posted February 15, 2022. The copyright holder for this preprint (which was not certified by peer review) is the author/funder, who has granted medRxiv a license to display the preprint in

It is made available under a CC-BY-ND 4.0 International license .

methods and experimental validation, can help to understand possible transmission pathways and inform efforts to mitigate transmission.

\section{Acknowledgements}

This work was motivated and enabled by the work and discussions co-led by Professors Paul Linden (pfl4@cam.ac.uk) and Christopher Pain (c.pain@imperial.ac.uk) under Task 7 (Environmental and aerosols transmission) of the Royal Society's 'Rapid Modelling of the Pandemic project' (RAMP).

\section{References}

Adenaiye, O. O., Lai, J., de Mesquita, P. J. B., Hong, F. H., Youssefi, S., German, J. R., ... others (2021). Infectious sars-cov-2 in exhaled aerosols and efficacy of masks during early mild infection. medRxiv.

Almstrand, A. C., Bake, B., Ljungström, E., Larsson, P., Bredberg, A., Mirgorodskaya, E., \& Olin, A. C. (2010). Effect of airway opening on production of exhaled particles. Journal of Applied Physiology, 108(3), 584-588.

Alsved, M., Matamis, A., Bohlin, R., Richter, M., Bengtsson, P.-E., Fraenkel, C.-J., ... Löndahl, J. (2020). Exhaled respiratory particles during singing and talking. Aerosol Science and Technology, 54(11), 1245-1248.

Asadi, S., Wexler, A. S., Cappa, C. D., Barreda, S., Bouvier, N. M., \& Ristenpart, W. D. (2019). Aerosol emission and superemission during human speech increase with voice loudness. Scientific Reports, 9(1), 1-10.

Bake, B., Larsson, P., Ljungkvist, G., Ljungström, E., \& Olin, A. (2019). Exhaled particles and small airways. Respiratory Research, 20(1), 8.

Baurès, E., Blanchard, O., Mercier, F., Surget, E., le Cann, P., Rivier, A., ... Florentin, A. (2018). Indoor air quality in two french hospitals: Measurement of chemical and microbiological contaminants. Science of The Total Environment, 642, 168-179. Retrieved from https://www.sciencedirect.com/science/article/pii/S0048969718321156

Beggs, C. B., Kerr, K. G., Noakes, C. J., Hathway, E. A., \& Sleigh, P. A. (2008). The ventilation of multiple-bed hospital wards: Review and analysis. American Journal of Infection Control, 36(4), 250-259. Retrieved from https://www.sciencedirect.com/science/article/pii/S0196655307008000

Binkowitz, B. S., \& Wartenberg, D. (2001). Disparity in quantitative risk assessment: A review of input distributions. Risk Analysis, 21(1), 75-90.

Bourouiba, L. (2020). Turbulent gas clouds and respiratory pathogen emissions: potential implications for reducing transmission of covid-19. JAMA, 323(18), 1837-1838.

Bourouiba, L. (2021a). The fluid dynamics of disease transmission. Annual Review of Fluid Mechanics, 53, 473-508.

Bourouiba, L. (2021b). Fluid dynamics of respiratory infectious diseases. Annual Review of Biomedical Engineering, 23, 547-577.

Bourouiba, L., Dehandschoewercker, E., \& Bush, J. W. (2014). Violent expiratory events: on coughing and sneezing. Journal of Fluid Mechanics, 745, 537-563. 
Bullard, J., Dust, K., Funk, D., Strong, J. E., Alexander, D., Garnett, L., ... others (2020). Predicting infectious severe acute respiratory syndrome coronavirus 2 from diagnostic samples. Clinical Infectious Diseases, 71 (10), 2663-2666.

Burridge, H. C., Bhagat, R. K., Stettler, M. E., Kumar, P., De Mel, I., Demis, P., ... others (2021). The ventilation of buildings and other mitigating measures for covid-19: a focus on wintertime. Proceedings of the Royal Society A, 477(2247), 20200855.

Cevik, M., Tate, M., Lloyd, O., Maraolo, A. E., Schafers, J., \& Ho, A. (2021). SARS-CoV-2, SARS$\mathrm{CoV}$, and MERS-CoV viral load dynamics, duration of viral shedding, and infectiousness: a systematic review and meta-analysis. The Lancet Microbe, 2(1), e13-e22.

Chao, C., Wan, M., Morawska, L., Johnson, G., Ristovski, Z., Hargreaves, M., ... Katoshevski, D. (2009). Characterization of expiration air jets and droplet size distributions immediately at the mouth opening. Journal of Aerosol Science, 40(2), 122 - 133.

Chaudhuri, S., Basu, S., \& Saha, A. (2020). Analyzing the dominant sars-cov-2 transmission routes toward an ab initio disease spread model. Physics of Fluids, 32(12), 123306.

ChemSpider. (2020). Colfosceril palmitate, C40H80NO8P, ChemSpider. Retrieved 2020-12-10, from http://www. chemspider.com/Chemical-Structure.398235.html

Cheng, Y., Ma, N., Witt, C., Rapp, S., Wild, P. S., Andreae, M. O., ... Su, H. (2021). Face masks effectively limit the probability of sars-cov-2 transmission. Science.

Chia, P. Y., Coleman, K. K., Tan, Y. K., Ong, S. W. X., Gum, M., Lau, S. K., .. others (2020). Detection of air and surface contamination by SARS-CoV-2 in hospital rooms of infected patients. Nature Communications, 11(1), 1-7.

Coleman, K. K., Tay, D. J. W., Sen Tan, K., Ong, S. W. X., Son, T. T., Koh, M. H., ... Wai, T. K. (2021, 08). Viral Load of SARS-CoV-2 in Respiratory Aerosols Emitted by COVID-19 Patients while Breathing, Talking, and Singing. Clinical Infectious Diseases. Retrieved from https://doi.org/10.1093/cid/ciab691 (ciab691)

Dabisch, P., Schuit, M., Herzog, A., Beck, K., Wood, S., Krause, M., ... others (2020). The influence of temperature, humidity, and simulated sunlight on the infectivity of SARS-CoV-2 in aerosols. Aerosol Science and Technology, 1-12.

De Vecchi, R., Candido, C., de Dear, R., \& Lamberts, R. (2017). Thermal comfort in office buildings: Findings from a field study in mixed-mode and fully-air conditioning environments under humid subtropical conditions. Building and Environment, 123, 672-683. Retrieved from https://www.sciencedirect.com/science/article/pii/S0360132317303281

de Oliveira, P. M., Mesquita, L. C. C., Gkantonas, S., Giusti, A., \& Mastorakos, E. (2021). Evolution of spray and aerosol from respiratory releases: theoretical estimates for insight on viral transmission. Proceedings of the Royal Society A: Mathematical, Physical and Engineering Sciences, 477(2245), 20200584. Retrieved from https://royalsocietypublishing.org/doi/abs/10.1098/rspa.2020.0584

Dhand, R., \& Li, J. (2020). Coughs and sneezes: their role in transmission of respiratory viral infections, including sars-cov-2. American journal of respiratory and critical care medicine, 202(5), 651-659.

Ding, Z., Qian, H., Xu, B., Huang, Y., Miao, T., Yen, H.-L., .. Li, Y. (2021). Toilets dominate environmental detection of severe acute respiratory syndrome coronavirus 2 in a hospital. Science of The Total Environment, 753, 141710.

Döhla, M., Wilbring, G., Schulte, B., Kümmerer, B. M., Diegmann, C., Sib, E., .. others (2020). SARS-CoV-2 in environmental samples of quarantined households. medRxiv. 
Duguid, J. P. (1946). The size and the duration of air-carriage of respiratory droplets and dropletnuclei. Journal of Hygiene, $44(6), 471-479$.

Education and Skills Funding Agency (ESFA). (2018). Building Bulletin 101 Guidelines on ventilation, thermal comfort and indoor air quality in schools (Tech. Rep.). Retrieved from https://www.gov.uk/government/publications/building-bulletin-101-ventilation-for-schoo]

Edwards, D. A., Ausiello, D., Salzman, J., Devlin, T., Langer, R., Beddingfield, B. J., ... Roy, C. J. (2021, feb). Exhaled aerosol increases with COVID-19 infection, age, and obesity. Proceedings of the National Academy of Sciences of the United States of America, 118(8). Retrieved from https://doi.org/10.1073/pnas. 2021830118

Effros, R., Hoagland, K., Bosbous, M., Castillo, D., Foss, B., Dunning, M., ... Sun, F. (2002). Dilution of respiratory solutes in exhaled condensates. American Journal of Respiratory and Critical Care Medicine, 165(5), 663-669. Retrieved from https://doi.org/10.1164/ajrccm.165.5.2101018 (PMID: 11874811)

Feng, B., Xu, K., Gu, S., Zheng, S., Zou, Q., Xu, Y., ... others (2021). Multi-route transmission potential of SARS-CoV-2 in healthcare facilities. Journal of Hazardous Materials, 402, 123771.

Gehan, E. A., \& George, S. L. (1970). Estimation of human body surface area from height and weight 12. Cancer Chemotherapy Reports, 54(4), 225.

Gould, J. M., \& Weiser, J. N. (2001). Expression of c-reactive protein in the human respiratory tract. Infection and Immunity, 69(3), 1747-1754.

Green, D. W., \& Perry, R. H. (2019). Perry's Chemical Engineers' Handbook (No. C 660.28 P47 2008.).

Gregson, F. K., Watson, N. A., Orton, C. M., Haddrell, A. E., McCarthy, L. P., Finnie, T. J. R., ... others (2021). Comparing aerosol concentrations and particle size distributions generated by singing, speaking and breathing. Aerosol Science and Technology, 1-14.

Gupta, J. K., Lin, C.-H., \& Chen, Q. (2010). Characterizing exhaled airflow from breathing and talking. Indoor Air, 20(1), 31-39.

Günther, T., Czech-Sioli, M., Indenbirken, D., Robitaille, A., Tenhaken, P., Exner, M., .. Brinkmann, M. M. (2020). Sars-cov-2 outbreak investigation in a german meat processing plant. EMBO Molecular Medicine, 12(12), e13296. Retrieved from https ://www . embopress .org/doi/abs/10.15252/emmm. 202013296

Hamilton, F. W., Gregson, F. K. A., Arnold, D. T., Sheikh, S., Ward, K., Brown, J., ... Dodd, J. W. (2021). Aerosol emission from the respiratory tract: an analysis of aerosol generation from oxygen delivery systems. Thorax. Retrieved from https://thorax.bmj.com/content/early/2021/11/01/thoraxjnl-2021-217577

Hanif, J., Jawad, S., \& Eccles, R. (2000). The nasal cycle in health and disease. Clinical Otolaryngology \& Allied Sciences, 25(6), 461-467.

Hassoun, M., Royall, P. G., Parry, M., Harvey, R. D., \& Forbes, B. (2018). Design and development of a biorelevant simulated human lung fluid. Journal of Drug Delivery Science and Technology, 47, 485-491. Retrieved from https://www. sciencedirect.com/science/article/pii/S1773224718305951

Haynes, W. M. (2013). CRC Handbook of Chemistry and Physics (94th ed.). CRC Press.

Huang, C.-G., Lee, K.-M., Hsiao, M.-J., Yang, S.-L., Huang, P.-N., Gong, Y.-N., . . others (2020). Culture-based virus isolation to evaluate potential infectivity of clinical specimens tested for 
covid-19. Journal of clinical microbiology, 58(8), e01068-20.

ICRP. (1994). Human Respiratory Tract Model for Radiological Protection. ICRP Publication 66. Ann. ICRP 24 (1-3) (Tech. Rep.). Retrieved from https://www.icrp.org/publication.asp?id=icrp publication 66

Jiang, J. J., Hanna, R. B., Willey, M. V., \& Rieves, A. (2016). The measurement of airflow using singing helmet that allows free movement of the jaw. Journal of Voice, 30(6), 641-648. Retrieved from https://www.sciencedirect.com/science/article/pii/S0892199715001666

Johnson, G. R., \& Morawska, L. (2009). The mechanism of breath aerosol formation. Journal of Aerosol Medicine and Pulmonary Drug Delivery, 22(3), 229-237.

Johnson, G. R., Morawska, L., Ristovski, Z. D., Hargreaves, M., Mengersen, K., Chao, C. Y. H., ... others (2011). Modality of human expired aerosol size distributions. Journal of Aerosol Science, 42(12), 839-851.

Kim, M.-C., Cui, C., Shin, K.-R., Bae, J.-Y., Kweon, O.-J., Lee, M.-K., .. Chung, J.-W. (2021). Duration of culturable SARS-CoV-2 in hospitalized patients with COVID-19. New England Journal of Medicine, O(0). Retrieved from https://doi.org/10.1056/NEJMc2027040

Kumar, A., Terakosolphan, W., Hassoun, M., Vandera, K.-K., Novicky, A., Harvey, R., ... Forbes, B. (2017, Dec 01). A biocompatible synthetic lung fluid based on human respiratory tract lining fluid composition. Pharmaceutical Research, 34(12), 2454-2465. Retrieved from https://doi.org/10.1007/s11095-017-2169-4

Lednicky, J. A., Lauzard, M., Fan, Z. H., Jutla, A., Tilly, T. B., Gangwar, M., ... others (2020). Viable SARS-CoV-2 in the air of a hospital room with COVID-19 patients. International Journal of Infectious Diseases, 100, 476-482.

Lednicky, J. A., Lauzardo, M., Alam, M. M., Elbadry, M. A., Stephenson, C. J., Gibson, J. C., \& Morris, J. G. (2021). Isolation of SARS-CoV-2 from the air in a car driven by a COVID patient with mild illness. International Journal of Infectious Diseases, 108, 212-216.

Leung, N. H., Chu, D. K., Shiu, E. Y., Chan, K.-H., McDevitt, J. J., Hau, B. J., . . others (2020). Respiratory virus shedding in exhaled breath and efficacy of face masks. Nature medicine, 26(5), 676-680.

Lieber, C., Melekidis, S., Koch, R., \& Bauer, H.-J. (2021). Insights into the evaporation characteristics of saliva droplets and aerosols: Levitation experiments and numerical modeling. Journal of Aerosol Science, 154, 105760. Retrieved from https://www.sciencedirect.com/science/article/pii/S0021850221004936

Lin, K., \& Marr, L. C. (2020). Humidity-dependent decay of viruses, but not bacteria, in aerosols and droplets follows disinfection kinetics. Environmental Science \& Technology, 54(2), 10241032 .

Lin, Y.-C., Malotte, R. G., Ward, L., Kiplagat, L., Pabbaraju, K., Gill, K., .. Conly, J. M. (2021). Detection and quantification of infectious severe acute respiratory coronavirus-2 in diverse clinical and environmental samples from infected patients: Evidence to support respiratory droplet, and direct and indirect contact as singificant modes of transmission. Pre-print, "”.

Lindsley, W. G., Green, B. J., Blachere, F. M., Martin, S. B., Law, B., Jensen, P., \& Schafer, M. (2017). Sampling and characterization of bioaerosols. NIOSH manual of analytical methods, 5th edition. Cincinnati: National Institute for Occupational Safety and Health, Centers for Disease Control and Prevention.

Liu, Y., Ning, Z., Chen, Y., Guo, M., Liu, Y., Gali, N. K., .. Lan, K. (2020). Aerodynamic 
analysis of SARS-CoV-2 in two Wuhan hospitals. Nature, 86(21), 2020.03.08.982637.

Loudon, R. G., \& Roberts, R. M. (1967). Droplet expulsion from the respiratory tract. American Review of Respiratory Disease, 95(3), 435-442.

Ma, J., Qi, X., Chen, H., Li, X., Zhang, Z., Wang, H., ... others (2020). Coronavirus disease 2019 patients in earlier stages exhaled millions of severe acute respiratory syndrome coronavirus per hour. Clinical Infectious Diseases.

Madas, B. G., Füri, P., Farkas, Á., Nagy, A., Czitrovszky, A., Balásházy, I., .. Horváth, A. (2020). Deposition distribution of the new coronavirus (SARS-CoV-2) in the human airways upon exposure to cough-generated droplets and aerosol particles. Scientific reports, 10(1), 1-8.

Malashenko, A., Tsuda, A., \& Haber, S. (2009). Propagation and breakup of liquid menisci and aerosol generation in small airways. Journal of Aerosol Medicine and Pulmonary Drug Delivery, 22(4), 341-353.

Marks, M., Millat-Martinez, P., Ouchi, D., h Roberts, C., Alemany, A., Corbacho-Monné, M., ... others (2021). Transmission of covid-19 in 282 clusters in catalonia, spain: a cohort study. The Lancet Infectious Diseases.

Marr, L. C., Tang, J. W., Van Mullekom, J., \& Lakdawala, S. S. (2019). Mechanistic insights into the effect of humidity on airborne influenza virus survival, transmission and incidence. Journal of The Royal Society Interface, 16(150), 20180298.

McGill, G., Oyedele, L. O., \& McAllister, K. (2015). Case study investigation of indoor air quality in mechanically ventilated and naturally ventilated uk social housing. International Journal of Sustainable Built Environment, 4(1), 58-77. Retrieved from https://www.sciencedirect.com/science/article/pii/S2212609015000096

Michnik, A. (2003). Thermal stability of bovine serum albumin DSC study. Journal of Thermal Analysis and Calorimetry, 71 (2), 509-519.

Milton, D. K. (2020). A rosetta stone for understanding infectious drops and aerosols. Oxford University Press US.

Milton, D. K., Fabian, M. P., Cowling, B. J., Grantham, M. L., \& McDevitt, J. J. (2013). Influenza virus aerosols in human exhaled breath: particle size, culturability, and effect of surgical masks. PLoS pathogens, 9(3), e1003205.

Mittal, R., Ni, R., \& Seo, J.-H. (2020). The flow physics of COVID-19. Journal of fluid Mechanics, 894.

Mohamed, S., Rodrigues, L., Omer, S., \& Calautit, J. (2021). Overheating and indoor air quality in primary schools in the uk. Energy and Buildings, 250, 111291. Retrieved from https://www.sciencedirect.com/science/article/pii/S0378778821005752

Morawska, L., Johnson, G. R., Ristovski, Z. D., Hargreaves, M., Mengersen, K., Corbett, S., ... Katoshevski, D. (2009). Size distribution and sites of origin of droplets expelled from the human respiratory tract during expiratory activities. Journal of Aerosol Science, 40(3), 256269.

Moriarty, J. A., \& Grotberg, J. B. (1999). Flow-induced instabilities of a mucus-serous bilayer. Journal of Fluid Mechanics, 397, 1-22.

Morris, D. H., Yinda, K. C., Gamble, A., Rossine, F. W., Huang, Q., Bushmaker, T., ... LloydSmith, J. O. (2021, jul). Mechanistic theory predicts the effects of temperature and humidity on inactivation of SARS-CoV-2 and other enveloped viruses. eLife, 10. Retrieved from https://elifesciences.org/articles/65902

Nagle, J. F., \& Wilkinson, D. A. (1978). Lecithin bilayers. Density measurement and molecular 
interactions. Biophysical Journal, 23(2), 159-175.

NCBI. (2020). Pubchem compound summary for CID 452110, Colfosceril Palmitate. PubChem. Retrieved from https://pubchem.ncbi.nlm.nih.gov/compound/Colfosceril-palmitate

Nguyen, J. L., Schwartz, J., \& Dockery, D. W. (2014). The relationship between indoor and outdoor temperature, apparent temperature, relative humidity, and absolute humidity. Indoor Air, 24(1), 103-112. Retrieved from https://onlinelibrary.wiley.com/doi/abs/10.1111/ina.12052

Office for National Statistics. (2010). 'Average' Briton highlighted on UN World Statistics Day (Tech. Rep.). Office for National Statistics: Author.

Ong, S. W. X., Tan, Y. K., Coleman, K. K., Tan, B. H., Leo, Y.-S., Wang, D. L., ... et al. (2021). Lack of viable sars-cov-2 among pcr-positive air samples from hospital rooms and community isolation facilities. Infection Control and Hospital Epidemiology, 1-17.

Oreszczyn, T., Ridley, I., Hong, S. H., Wilkinson, P., \& Group, W. F. S. (2006). Mould and winter indoor relative humidity in low income households in england. Indoor and Built Environment, 15(2), 125-135. Retrieved from https://doi.org/10.1177/1420326X06063051

Papineni, R. S., \& Rosenthal, F. S. (1997). The size distribution of droplets in the exhaled breath of healthy human subjects. Journal of Aerosol Medicine: Deposition, Clearance, and Effects in the Lung, 10(2), 105-116.

Plante, J. A., Liu, Y., Liu, J., Xia, H., Johnson, B. A., Lokugamage, K. G., ... others (2021). Spike mutation d614g alters sars-cov-2 fitness. Nature, 592(7852), 116-121.

Prather, K. A., Marr, L. C., Schooley, R. T., McDiarmid, M. A., Wilson, M. E., \& Milton, D. K. (2020). Airborne transmission of SARS-CoV-2. Science.

Quraishi, S. A., Berra, L., \& Nozari, A. (2020). Indoor temperature and relative humidity in hospitals: workplace considerations during the novel coronavirus pandemic. Occupational and Environmental Medicine, 777(7), 508-508. Retrieved from https://oem.bmj.com/content/77/7/508

Redrow, J., Mao, S., Celik, I., Posada, J. A., \& Feng, Z.-G. (2011). Modeling the evaporation and dispersion of airborne sputum droplets expelled from a human cough. Building and Environment, 46(10), 2042-2051. Retrieved from https://www.sciencedirect.com/science/article/pii/S0360132311001132

Roque, M., Proudfoot, K., Mathys, V., Yu, S., Krieger, N., Gernon, T., .. Fong, Y. (2021). A review of nasopharyngeal swab and saliva tests for sars-cov-2 infection: Disease timelines, relative sensitivities, and test optimization. Journal of Surgical Oncology, 124(4), 465-475. Retrieved from https://onlinelibrary.wiley.com/doi/abs/10.1002/jso. 26561

Ryan, D. J., Toomey, S., Madden, S. F., Casey, M., Breathnach, O. S., Morris, P. G., ... others (2021). Use of exhaled breath condensate (ebc) in the diagnosis of SARS-COV-2 (COVID-19). Thorax, 76 (1), 86-88.

S, K., E, C., Y, B. D. B., \& E, D. O. F. (2014). Guidelines for healthy environments within european schools (Technical guidance No. LB-NA-26726-EN-N). Luxembourg (Luxembourg).

Santarpia, J. L., Rivera, D. N., Herrera, V. L., Morwitzer, M. J., Creager, H. M., Santarpia, G. W., ... others (2020). Aerosol and surface contamination of SARS-CoV-2 observed in quarantine and isolation care. Scientific Reports, 10(1), 1-8.

Shao, S., Zhou, D., He, R., Li, J., Zou, S., Mallery, K., ... Hong, J. (2020). Risk assessment of airborne transmission of COVID-19 by asymptomatic individuals under different practical settings. Journal of Aerosol Science, 151, 105661. 
Singanayagam, A., Patel, M., Charlett, A., Bernal, J. L., Saliba, V., Ellis, J., ... Gopal, R. (2020). Duration of infectiousness and correlation with RT-PCR cycle threshold values in cases of COVID-19, England, January to May 2020. Eurosurveillance, 25 (32), 2001483.

Stadnytskyi, V., Bax, C. E., Bax, A., \& Anfinrud, P. (2020). The airborne lifetime of small speech droplets and their potential importance in SARS-CoV-2 transmission. Proceedings of the National Academy of Sciences of the United States of America, 117(22), 11875-11877.

Stelzer-Braid, S., Oliver, B. G., Blazey, A. J., Argent, E., Newsome, T. P., Rawlinson, W. D., \& Tovey, E. R. (2009). Exhalation of respiratory viruses by breathing, coughing, and talking. Journal of Medical Virology, 81(9), 1674-1679.

Tanford, C. (1961). Physical chemistry of macromolecules. J. Wiley \& Sons.

Tu, Y.-P., Jennings, R., Hart, B., Cangelosi, G. A., Wood, R. C., Wehber, K., ... Berke, E. M. (2020). Swabs collected by patients or health care workers for sars-cov-2 testing. New England Journal of Medicine, 383(5), 494-496.

van Kampen, J. J., van de Vijver, D. A., Fraaij, P. L., Haagmans, B. L., Lamers, M. M., Okba, N., ... others (2021). Duration and key determinants of infectious virus shedding in hospitalized patients with coronavirus disease-2019 (COVID-19). Nature Communications, 12(1), 267.

Vejerano, E. P., \& Marr, L. C. (2018). Physico-chemical characteristics of evaporating respiratory fluid droplets. Journal of The Royal Society Interface, 15(139), 20170939.

Veldhuizen, E. J., \& Haagsman, H. P. (2000). Role of pulmonary surfactant components in surface film formation and dynamics. Biochimica et Biophysica Acta (BBA) - Biomembranes, 1467(2), 255-270. Retrieved from https://www.sciencedirect.com/science/article/pii/S000527360000256X

Walker, J. S., Archer, J., Gregson, F. K., Michel, S. E., Bzdek, B. R., \& Reid, J. P. (2021, jan). Accurate Representations of the Microphysical Processes Occurring during the Transport of Exhaled Aerosols and Droplets. ACS Central Science, 7(1), 200-209. Retrieved from https://dx.doi.org/10.1021/acscentsci.0c01522

Walsh, K. A., Jordan, K., Clyne, B., Rohde, D., Drummond, L., Byrne, P., ... Harrington, P. (2020). SARS-CoV-2 detection, viral load and infectivity over the course of an infection. Journal of Infection, $81(3), 357$ - 371.

Wang, B., Wu, H., \& Wan, X.-F. (2020). Transport and fate of human expiratory droplets-a modeling approach. Physics of Fluids, 32(8), 083307.

Warnke, P., Warning, L., \& Podbielski, A. (2014). Some are more equal-a comparative study on swab uptake and release of bacterial suspensions. PloS one, 9(7), e102215.

Watanabe, T., Bartrand, T. A., Weir, M. H., Omura, T., \& Haas, C. N. (2010). Development of a dose-response model for sars coronavirus. Risk Analysis: An International Journal, 30(7), $1129-1138$.

WHO. (2014). Infection prevention and control of epidemic-and pandemic-prone acute respiratory infections in health care (Tech. Rep.). Geneva, Switzerland: World Health Organization.

Wölfel, R., Corman, V. M., Guggemos, W., Seilmaier, M., Zange, S., Müller, M. A., ... others (2020). Virological assessment of hospitalized patients with COVID-2019. Nature, 581(7809), 465-469.

Wölfel, R., Corman, V. M., Guggemos, W., Seilmaier, M., Zange, S., Müller, M. A., ... Wendtner, C. (2020). Virological assessment of hospitalized patients with COVID-2019. Nature, 581 (7809), 465-469.

Wu, T., Cao, B., \& Zhu, Y. (2018). A field study on thermal comfort and air-conditioning energy 
medRxiv preprint doi: https://doi.org/10.1101/2022.02.11.22270844; this version posted February 15, 2022. The copyright holder for this preprint (which was not certified by peer review) is the author/funder, who has granted medRxiv a license to display the preprint in

It is made available under a CC-BY-ND 4.0 International license.

use in an office building in guangzhou. Energy and Buildings, 168, 428-437. Retrieved from https://www.sciencedirect.com/science/article/pii/S0378778817336174

Xie, X., Li, Y., Sun, H., \& Liu, L. (2009). Exhaled droplets due to talking and coughing. Journal of the Royal Society Interface, 6 .

Yamagishi, T., et al. (2020). Environmental sampling for severe acute respiratory syndrome coronavirus 2 (SARS-CoV-2) during a coronavirus disease (COVID19) outbreak aboard a commercial cruise ship. MedRxiv. Retrieved from https://www.medrxiv.org/content/early/2020/05/08/2020.05.02.20088567

Yan, J., Grantham, M., Pantelic, J., De Mesquita, P. J. B., Albert, B., Liu, F., .. others (2018). Infectious virus in exhaled breath of symptomatic seasonal influenza cases from a college community. Proceedings of the National Academy of Sciences, 115(5), 1081-1086.

Yang, S., Lee, G. W., Chen, C.-M., Wu, C.-C., \& Yu, K.-P. (2007). The size and concentration of droplets generated by coughing in human subjects. Journal of Aerosol Medicine, 20(4), 484-494.

Zhang, X. S., \& Duchaine, C. (2020). SARS-CoV-2 and health care worker protection in low-risk settings: a review of modes of transmission and a novel airborne model involving inhalable particles. Clinical Microbiology Reviews, 34(1).

Zhou, J., Otter, J. A., Price, J. R., Cimpeanu, C., Garcia, D. M., Kinross, J., .. others (2020). Investigating SARS-CoV-2 surface and air contamination in an acute healthcare setting during the peak of the COVID-19 pandemic in London. Clinical Infectious Diseases.

Zhou, L., Yao, M., Zhang, X., Hu, B., Li, X., Chen, H., ... others (2021). Breath-, air-and surface-borne SARS-CoV-2 in hospitals. Journal of Aerosol Science, 152, 105693. 